\title{
Use of the Cover Crop Weed Index to Evaluate Weed Suppression by Cover Crops in Organic Citrus Orchards
}

\author{
Jose Linares, Johannes Scholberg ${ }^{1}$, and Kenneth Boote \\ University of Florida, Agronomy Department, 304 Newell Hall, Gainesville, FL 32611-0500
}

Carlene A. Chase and James J. Ferguson

University of Florida, Horticultural Sciences Department, 1301 Fifield Hall, Gainesville, FL 32611-0690

\author{
Robert McSorley \\ University of Florida, Entomology and Nematology Department, Building 970, \\ Natural Area Drive, Gainesville, FL 32611-0620
}

\begin{abstract}
Additional index words. weed management, annual cover crops, summer cover crops, weed suppression index, winter cover crops, perennial peanut, Arachis glabrata

Abstract. Citrus is one of the most important crops in Florida. During the past decade, increased international competition and urban development, diseases, and more stringent environmental regulations have greatly affected the citrus industry. Citrus growers transitioning to organic production may benefit from premium prices, but they also face many challenges, including development of effective weed management strategies. Cover crops (CC) may constitute an environmentally sound alternative for improved weed management in organic systems. Two field experiments were conducted at Citra in north central Florida from 2002 to 2005 , to evaluate the effectiveness of annual and perennial CC to suppress weeds in organic citrus groves. To quantify and compare the effectiveness of $\mathrm{CC}$ to suppress weed growth, a new weed suppression assessment tool, the cover crop/weed index (CCWI), was developed using the ratio of biomass accumulation of $\mathrm{CC}$ and weeds. Annual summer CC accumulated more biomass in comparison with winter CC. Sunnhemp (Crotalaria juncea L.), hairy indigo (Indigofera hirsuta L.), cowpea (Vigna unguiculata L. Walp.), and alyceclover (Alysicarpus vaginalis L.) all provided excellent weed suppression, which was superior to tillage fallow. Single-species winter CC did not always perform consistently well. Use of winter $\mathrm{CC}$ mixtures resulted in more consistent overall $\mathrm{CC}$ performance, greater dry matter production, and more effective weed suppression than single species of $C C$. Initial perennial peanut (PP) growth was slow, and summer planting of PP (Arachis glabrata Benth.) was determined to be the most effective date in terms of weed suppression, which was improved gradually over time, but all planting dates resulted in slow initial growth compared with annual CC. For both PP and annual CC, weed biomass typically was inversely related to CC dry weight accumulation resulting from competition for resources. The CCWI was a suitable tool to quantify $\mathrm{CC}$ performance in terms of weed suppression.
\end{abstract}

Florida is the largest citrus-producing state in the United States, and with 302,929 ha bearing fruit it, accounts for $74 \%$ of U.S citrus production (Florida Agricultural Statistics Service, 2006). Total crop value of Florida citrus during 2004-2005 was US\$742 million. However, conventional citrus growers are facing increased international competition, relatively low citrus prices, new virulent diseases, competition with residential development for land and water resources, and more stringent environmental regulations (Athearn, 2004).

Because excessive use of potentially harmful agrochemicals may affect biodiversity, environmental quality, food safety, and farmers' health, there is increased interest in more sustainable production systems including organic farming (Reganold et al., 2001). With reduced synthetic pesticide and fertilizer use, organic production can preserve both groundwater resources and fragile ecosystems (Mader et al., 2002). Conversion to organic production also allows growers to benefit from special marketing niches and grower-friendly price mechanisms (Athearn, 2004).

Weeds compete with crops for water, nutrients, and light. Serving as potential hosts for insect pests and diseases, weeds can also

${ }^{1}$ To whom reprint requests should be addressed; email jmscholberg@ifas.ufl.edu. interfere with soil tillage, irrigation, and harvest operations (Liebman and Davis, 2000), and thereby increase labor requirements and production costs. Adequate weed control is one of the main challenges during the conversion to organic systems. Changes in weed population dynamics during this process requires implementation of alternative weed management strategies (Bond and Grundy, 2001).

Weed management has been identified as the primary concern of organic farmers (Sooby, 2003; Walz, 1999). For organic citrus groves, weed control accounted for more than $30 \%$ of annual production costs and the majority of the labor costs (Muraro et al., 2003). Included in these costs are disking, mowing, and hand labor to remove vines growing into tree canopies or weeds near tree trunks of young trees. The majority of Florida citrus growers interviewed in 2001 expressed a strong interest in the use of cover crops (CC) to prevent soil degradation and to suppress weed growth (Scholberg, unpublished).

Cover crops may suppress weeds by either reducing resource availability (Ngouajio and Mennan, 2005) or by inhibiting weed growth via allelopathy (Reberg-Horton et al., 2005). Access to light, nutrients, water, and soil as affected by CC may affect weed persistence (Ngouajio and Mennan, 2005) and the composition of weed flora in citrus groves (Wright et al., 2003). Cover crop residues may also alter soil microbial ecology or increase microbial diversity, resulting in enhanced weed seed predation by soil microorganisms and decreased weed seed vigor (Gallagher et al., 1999; Ngouajio and McGiffen, 2002), or may affect weed population dynamics (Jordan et al., 2000). Cover crops may also increase soil $\mathrm{C}$ and $\mathrm{N}$ content, two principal components regulating soil biological activity (Wagger et al., 1998), and thus increase the presence of beneficial organisms that suppress biological competitors such as weeds (Kremer and Li, 2003), parasitic nematodes (Wang et al., 2006), and soil pathogens via allelochemicals (Bailey and Lazarovits, 2003).

Successful weed suppression using summer $\mathrm{CC}$ has been reported for annual crops such as rice (Oryza sativa L.) preceded by pigeon pea (Cajanus cajan L.) as a CC (Roder et al., 1998), and corn (Zea mays L.) by using velvet bean (Mucuna atropurpureum L.) (Caamal-Maldonado et al., 2001). Using annual winter $\mathrm{CC}$ such as winter rye (Secale cereale L.) (Fennimore and Jackson, 2003) or crimson clover (Trifolium incarnatum L.) and subterranean clover (Trifolium subterraneum L.) (Barberi and Mazzoncini, 2001) may provide adequate weed control for the following corn crop.

Perennial peanut (PP) is a warm-season perennial legume with a wide area of adaptation ranging from $31^{\circ} \mathrm{N}$ to $35^{\circ} \mathrm{S}$ latitude (Prine et al., 1981). Reported uses of PP 
include soil conservation, pasture, hay, and a replacement for turf (French et al., 2001). Because of low water and nutrient requirements and the absence of serious pests (Baltensperger et al., 1986, French et al., 2001), PP may provide an environmentally sound and ecologically important component of sustainable citrus production in Florida (Mullahey et al., 1994). When mowed two to three times a year, PP can also provide 60 to $112 \mathrm{~kg} \cdot \mathrm{ha}^{-1} \cdot$ year $^{-1} \mathrm{~N}$ to citrus trees or alternatively serve as a high-value forage. Some citrus growers may thus opt to use PP to enhance the sustainability and profitability of their citrus production systems as well.

Successful weed suppression via use of a perennial CC has been reported by PerezNieto et al. (2005) in coffee by using Arachis pintoi L. (nonrhizomal PP). Although the use of annual CC and PP in conventional citrus and vegetables systems in South Florida has been studied extensively (Mullahey et al., 1994; Roe et al., 1994; Rouse and Mullahey, 1997), before this study, no information was available regarding the effectiveness of annual and perennial $\mathrm{CC}$ in suppressing weeds in organic citrus production systems.

Most studies typically report the effectiveness of $\mathrm{CC}$ in suppressing weeds in qualitative terms such as providing "adequate" weed control. But there is a lack of a universally applicable and more accurate index to quantify the effectiveness of cover crops in suppressing weeds across production environments. We therefore designed a new index that can be used as a management tool to evaluate the effectiveness of CC in suppressing weeds by calculating the ratio of biomass of both CC and weeds. We devised the term cover crop weed index (CCWI) for this ratio.

The overall objectives of this study were 1) to identify suitable $\mathrm{CC}$ species for weed suppression in organic citrus groves, 2) to develop a quantitative index for assessing the effectiveness of CC in suppressing weeds in an organic citrus system, 3) to contrast the performance and weed growth dynamics of PP-based systems with that of annual CC systems via the use of this index, 4) to evaluate changes in weed growth as affected by annual and perennial CC treatments, and 5) identify optimal $\mathrm{CC}$ mixtures suited for organic citrus production. The following hypotheses were tested in organic citrus systems: 1) annual CC will suppress weeds more effectively compared with PP, and 2) summer CC will accumulate more biomass and consequently will suppress weeds more effectively than winter CC.

\section{MATERIALS AND METHODS}

\section{Plot establishment and experimental design}

The study was conducted from 2002 to 2005 at a Certified Organic Research site at the University of Florida Plant Sciences Research and Education Unit in Citra, FL $\left(29^{\circ} 24^{\prime} 40^{\prime \prime} \mathrm{N}, 82^{\circ} 08^{\prime} 56^{\prime \prime} \mathrm{W}\right)$. Soil types at the experimental site were Candler and
Tavares fine sand $(\approx 97 \%$ to $98 \%$ sand in the upper $15 \mathrm{~cm}$ ). The initial soil $\mathrm{pH}$ ranged from 4.8 to 5.1 , and soil organic matter content was $5.4 \mathrm{~g} \cdot \mathrm{kg}^{-1} \mathrm{C}$.

Two 1-ha blocks were planted with 'Hamlin' and 'Navel' orange varieties [Citrus sinensis (L.) Osb.] on Swingle citrumelo [C. paradisi Macf. $\times P$. trifoliata (L.) Raf.] rootstocks during the summer of 2002 (Hamlin) and Spring 2003 (Navel). Tree spacing was $4.2 \mathrm{~m}$ in the row and $6.1 \mathrm{~m}$ between rows. Two separate experiments were conducted. The main emphasis of the first study was on annual CC, and this study is hereafter referred to as the annual CC study (ACC). Summer and winter cover crops were planted in June (summer CC) and November (winter CC) and mowed and rototilled in October and April respectively. Annual cover crop treatments (2002 and 2003) and 2 (2004 and 2005). Each $\mathrm{CC}$ treatment plot consisted of a total area of $6.1 \mathrm{~m} \times 27 \mathrm{~m}$ adjacent to a tree row of five citrus trees. Cover crop treatments were arranged using a randomized complete block design with four replications, and CC (summer vs. winter CC) were planted twice a year. During 2002, only a grass fallow was used as the control, whereas starting in 2003, a tillage fallow was also included as an experimental treatment. After initial establishment, grass fallow plots were mowed at 3- to 4-week intervals throughout the spring, summer, and fall, whereas tillage fallows were tilled twice a year before $\mathrm{CC}$ planting. Annual $\mathrm{CC}$ were planted with a "zero-till" planter (Sukup 2100; Sukup Manufacturing Co., Shefield, IA) using appropriate row spacing and recommended planting rates. Except for grass fallows and winter CC planted in 2003, when and their sequence are outlined in Tables 1

a zero-tillage system was used, residues or weeds were soil incorporated with two to three passes of a rototiller before planting CC.

The main focus of the second study, hereafter referred to as the perennial CC study (PCC), was on PP as a CC. A randomized complete block design was used with four replications and included four groundcover treatments in the 4.2-m-wide row middles: 1) ACC, sunnhemp, or cowpea planted in summer, crimson clover, or winter rye, and in 2004-05 a triple mix of winter rye + crimson clover + radish (Raphanus sativus cv. Rufus) planted in fall (nonperennial CC); 2) $P P$ planted in the spring $\left.\left(\mathrm{PP}_{\mathrm{sp}}\right) ; 3\right)$ crimson clover planted in the spring (2002) and PP planted in the summer [in 2003, 2004, and 2005, PP was overseeded with crimson clover in the fall $\left.\left(\mathrm{PP}_{\text {su-os }}\right)\right]$; and 4$)$ and fallow in spring (2002) and PP planted in summer $\left(\mathrm{PP}_{\mathrm{su}}\right)$. Each plot consisted of a total area of $18.9 \times 27.0 \mathrm{~m}$, and plots contained three row middles and two tree rows of five trees each. For ACC and PP plots overseeded with crimson clover in fall $\left(\mathrm{PP}_{\text {su-os }}\right)$, groundcovers were planted as discussed earlier.

'Florigraze' PP was planted in Mar. and July 2002 for spring and summer treatments, respectively, with a rhizome planting rate of $10 \mathrm{~m}^{3} \cdot \mathrm{ha}^{-1}$, using a bermudagrass planter (model no. 79; Bermuda King, Kingfisher, $\mathrm{OK}$ ) with a row spacing of $0.5 \mathrm{~m}$. After initial establishment, PP-based treatments plots were mowed at 4-week intervals during spring, summer, and fall. After each sampling, PPbased systems were mowed.

All annual leguminous $\mathrm{CC}$ were inoculated before planting with the appropriate strain of rhizobium (Nitragin brand, Milwaukee, WI). Cover crops were irrigated only at

Table 1. Overview of annual summer and winter cover crops used during the 2002 and 2003 growing seasons.

\begin{tabular}{|c|c|c|}
\hline \multirow[b]{2}{*}{ Treatment } & \multicolumn{2}{|c|}{ Cropping Season } \\
\hline & Summer & Winter/spring \\
\hline \multicolumn{3}{|l|}{2002} \\
\hline 1 & $\begin{array}{l}\text { 'Iron Clay’ cowpea } \\
\quad \text { (Vigna unguiculata L. Walp.) }\end{array}$ & Crimson clover (Trifolium incarnatum L.) \\
\hline 2 & $\begin{array}{l}\text { Velvet bean } \\
\text { (Mucuna atropurpureum L.) DC) }\end{array}$ & Red clover (Trifolium pratense L.) \\
\hline 3 & Sunnhemp (Crotalaria juncea L.) & $\begin{array}{l}\text { Lupin/Cahaba vetch } \\
\quad \text { (Lupinus angustifolius } \text { L./Vicia sativa } \mathrm{L} .)\end{array}$ \\
\hline 4 & Alyceclover (Alysicarpus vaginalis L.) & Winter rye (Secale cereale L.) \\
\hline 5 & Hairy indigo (Indigofera hirsuta L.) & $\begin{array}{l}\text { Berseem clover/Sweet clover (Trifolium } \\
\text { alexandrinum L./Melilotus officinalis L.) }\end{array}$ \\
\hline 6 & Grass fallow & Grass fallow \\
\hline \multicolumn{3}{|l|}{2003} \\
\hline 1 & Sunnhemp/‘Iron Clay’ cowpea & $\begin{array}{l}\text { Winter rye/Hairy vetch } \\
\quad(\text { S. cereale/Vicia villosa } \text { Roth })\end{array}$ \\
\hline 2 & 'Iron Clay' cowpea & Crimson clover \\
\hline 3 & Velvet bean & Radish (Raphanus sativus cv. Rufus) \\
\hline 4 & Hairy indigo & $\begin{array}{l}\text { Black oat/Lupin (Avena strigosa } \\
\text { Schreb/Lupinus angustifolius L.) }\end{array}$ \\
\hline 5 & Lablab (Lablab purpureus L.) & $\begin{array}{l}\text { Subterranean clover } \\
\quad \text { (Trifolium subterraneum L.) }\end{array}$ \\
\hline 6 & Peanut (Arachis hypogea L.) & Lupin \\
\hline 7 & $\begin{array}{l}\text { Perennial peanut } \\
\quad \text { (Arachis glabrata } \text { Benth.) }\end{array}$ & Perennial peanut \\
\hline 8 & Grass fallow & Grass fallow \\
\hline 9 & Tillage fallow & Tillage fallow \\
\hline 10 & Alyceclover & - \\
\hline
\end{tabular}


planting if soil moisture was inadequate to ensure uniform germination. In this case, 25 $\mathrm{mm} \cdot \mathrm{ha}^{-1}$ of irrigation was applied uniformly to the entire field to mimic a typical rainfall.

In Dec. 2001, four composite soil samples were taken from both experiments (ACC and PCC) and were analyzed for $\mathrm{pH}$, organic matter, and macro- and micronutrients. The results were used to determine the need for lime and $\mathrm{K}$ applications. During the spring of 2002 , lime $\left(2.5 \mathrm{Mg} \cdot \mathrm{ha}^{-1}\right)$ was applied to the entire area whereas chicken manure (2.5 $\mathrm{Mg} \cdot \mathrm{ha}^{-1}$ ) was broadcast during the ACC study and lightly incorporated into the soil via rototilling. In the PCC study, manure was applied exclusively to a 1.8 -m-wide strip adjacent to tree rows, and this procedure was repeated for both studies during subsequent years. Manure was applied in March and application rates were based on estimated manure $\mathrm{N}$ mineralization and $\mathrm{N}$ concentration following $\mathrm{N}$ recommendations for newly planted trees (Tucker et al., 1995). Because of the low soil $\mathrm{K}$ content $\left(2.4 \mathrm{mg} \cdot \mathrm{kg}^{-1}\right.$ Mehlich-1), an Organic Materials Review Institute (OMRI)-approved nonsynthetic (mined) $\mathrm{K}_{2} \mathrm{SO}_{4}$ fertilizer (SQM North America Corp., Atlanta, Ga) was applied to the entire area at a rate of $45 \mathrm{~kg} \cdot \mathrm{ha}^{-1} \mathrm{~K}_{2} \mathrm{O}$ before planting of winter $\mathrm{CC}$ to enhance their growth. As a result of a buildup of residual soil $\mathrm{P}$ (Mehlich-1 $\mathrm{P}>100 \mathrm{mg} \cdot \mathrm{kg}^{-1} \mathrm{P}$ ), use of chicken manure was discontinued after 2004. Starting in 2005, an OMRI-approved 9N-0 $\mathrm{P}_{2} \mathrm{O}_{5}-9 \mathrm{~K}_{2} \mathrm{O}$ natural fertilizer derived from feather meal and $\mathrm{K}_{2} \mathrm{SO}_{4}$ fertilizer (Nature Safe; Griffin Industries, Cold Spring, KY) was applied to tree rows following Institute of Food and Agricultural Science (IFAS) N and $\mathrm{K}$ recommendations for newly planted trees (Tucker et al., 1995).

\section{Data collection and measurements}

For the ACC study, representative sections of row middles of CC and weeds were clipped at ground level at monthly intervals to evaluate aboveground $\mathrm{CC}$ and weed biomass using rectangular sampling frames with an area of $0.22 \mathrm{~m}^{2}$. For the PCC study, representative sections of row middles were sampled at 8-week intervals using a rectangular sampling frame with an area of $0.5 \mathrm{~m}^{2}$ for one representative sample for each row middle, and three samples per plot. Weed biomass was not segregated into different weed species. Weeds and $\mathrm{CC}$ were harvested at ground level.

To quantify the effectiveness of ACC and PCC to suppress weed growth, we developed a CCWI. This index expresses CC growth and biomass dry weight $(\mathrm{DW})$ production $\left(\mathrm{CC}_{\mathrm{DW}}\right)$ relative to weed dry weight (Weed ${ }_{\mathrm{DW}}$ ) $\left(\mathrm{CCWI}=\mathrm{CC}_{\mathrm{DW}} / \mathrm{Weed}_{\mathrm{DW}}\right)$ for each sampled area. Shoots of CC and weeds were ovendried at $65{ }^{\circ} \mathrm{C}$ for $72 \mathrm{~h}$ until constant weight and DWs were recorded. A qualitative interpretation of this index is outlined in Table 3.

For the ACC study, analysis of variance was performed on all data using Proc GLM (SAS Institute, 2002). Means were compared

Table 2. Overview of annual summer and winter cover crops used during the 2004 and 2005 growing seasons.

\begin{tabular}{cll}
\hline & \multicolumn{2}{c}{ Cropping season } \\
\cline { 2 - 3 } Treatment & \multicolumn{1}{c}{ Summer } & \multicolumn{1}{c}{ Winter/Spring } \\
\hline 2004 & Sunnhemp/'Iron Clay' cowpea & \\
1 & 'Iron Clay' cowpea & Winter rye (WR) \\
2 & Hairy indigo & Crimson clover (CR) \\
3 & Velvet bean & Radish (R) \\
4 & Pigeon pea (Cajanus cajan L.) & Black oat (BO) \\
5 & Lablab & WR/CR \\
6 & Perennial peanut & BO/CR \\
7 & Grass fallow & Perennial peanut \\
8 & Tillage fallow & Grass fallow \\
9 & 'Cream-40' cowpea & Tillage fallow \\
10 & Mung bean (Vigna radiata (L.) R. Wilczek) & WR/CR/R \\
11 & Alyceclover & BO/CR/R \\
12 & & \\
2005 & Velvet bean/Sudan grass & \\
1 & Sunnhemp/'Iron Clay' cowpea & WR \\
2 & Hairy indigo & CR \\
3 & Alyceclover & R \\
4 & Lablab/velvet bean & Hairy vetch (HV) \\
5 & Lablab/sorghum-sudangrass (Sorghum bicolor L.) & WR/CR \\
6 & Perennial peanut & WR/CR/R \\
7 & Grass fallow & Perennial peanut \\
8 & Tillage fallow & Grass fallow \\
9 & Pigeon pea & Tillage fallow \\
10 & & WR/HV (67\% to 33\%) \\
11 & & WR/HV (33\% to 67\%) \\
\hline
\end{tabular}

${ }^{2}$ The mixture WR-HV contained $67 \%$ winter rye and $33 \%$ hairy vetch.

${ }^{y}$ The mixture WR-HV contained $33 \%$ winter rye and $67 \%$ hairy vetch.

$\mathrm{BO}$, black oat; $\mathrm{CR}$, crimson clover; $\mathrm{HV}$, hairy vetch; R, radish; WR, winter rye.

Table 3. Outline of cover crop weed index (CCWI) categories.

\begin{tabular}{|c|c|c|c|}
\hline CCWI value & Cover crop & Weeds & Weed control \\
\hline$<0.5$ & CC not competitive & Weeds predominate & $\begin{array}{l}\text { Very poor } \\
\quad(>70 \% \text { weeds) }\end{array}$ \\
\hline $0.5-1$ & $\mathrm{CC}$ coexist & Weeds coexist & Poor \\
\hline $1-3$ & CC starts prevailing & $\begin{array}{l}\text { Weeds prevail in certain } \\
\text { niches }\end{array}$ & Moderate \\
\hline $3-5$ & $\mathrm{CC}$ prevails & Weeds fail to predominate & Adequate \\
\hline $5-15$ & $\begin{array}{r}\text { CC predominate } \\
(70 \% \text { to } 90 \%)\end{array}$ & $<10 \%$ to $30 \%$ weeds & Excellent \\
\hline$>15^{z}$ & $\begin{array}{l}\text { CC predominate } \\
\text { completely }\end{array}$ & $<5 \%$ weeds & Outstanding \\
\hline
\end{tabular}

${ }^{\mathrm{Z}} \mathrm{It}$ is assumed that if the cover crop weed index (CCWI) is more than 15 , then weed control is considered outstanding, because weed cover only accounts for less than $5 \%$ of the total biomass. It should be noted that in the absence of weeds, the CCWI will approach infinity, and the upper boundary is thus not defined. $\mathrm{CC}$, cover crop.

using the Duncan multiple range test (DMRT) using a $P$ value of 0.05 . In the PCC study, the $\mathrm{PP}_{\mathrm{su}}$ treatment was compared with the ACC treatment. Shoot DW for ACC and PP, weed DWs in the same sampling unit, and the CCWI were evaluated using the DMRT with a $P$ value of 0.05 . The abbreviations outlined here will be used throughout the remainder of the paper. To compare means among years, analysis of variance was performed using Proc Mixed (SAS Institute., 2002), and LSMEANS $(P<0.05)$ to compare means within years.

\section{RESULTS AND DISCUSSION}

\section{Annual cover crop study}

Summer cover crop study. Summer CC had greater DW production capacity compared with winter CC. Sunnhemp biomass production was greater than all other CC in all years, with the exception of 2004, when hairy indigo was greater, whereas singlespecies velvet bean produced less biomass (Tables 4 and 5). Maximum sunnhemp plant height was $2.4 \mathrm{~m}$, causing some shading of the young citrus trees. Average heights for cowpea, hairy indigo, alyceclover, and velvet bean were $0.3,1.2,0.3$, and $0.3 \mathrm{~m}$ respectively (data not shown). During 2004, continuous cultivation of sunnhemp along with wet and windy conditions increased the dispersal and incidence of Verticillium spp. infection, thereby reducing biomass accumulation and weed suppression (CCWI $=2$ in 2004 vs. 64 in 2005 when the crop was properly rotated). Despite the superior performance of sunnhemp, continuous cultivation appears to be undesirable, and rotation with alternative $\mathrm{CC}$ such as cowpea should be practiced to prevent the buildup of soil-borne diseases. Overall sunnhemp DW accumulation was $10 \mathrm{Mg} \cdot \mathrm{ha}^{-1}$, which was similar to the findings of Ramos et al. (2001) and Perin 
Table 4. Cover crop (CC) shoot dry weight accumulation ( $\mathrm{DW}_{\mathrm{CC}}$ ), weed dry weight accumulation ( $\left.\mathrm{DW}_{\mathrm{WD}}\right)$, and cover crop weed index $(\mathrm{CCWI})$ for summer cover crops from 2002 to 2003.

\begin{tabular}{|c|c|c|c|c|c|c|}
\hline \multirow[b]{2}{*}{ Treatment } & \multicolumn{3}{|c|}{2002} & \multicolumn{3}{|c|}{2003} \\
\hline & $\overline{\mathrm{DW}_{\mathrm{CC}}\left(\mathrm{Mg} \cdot \mathrm{ha}^{-1}\right)}$ & $\mathrm{DW}_{\mathrm{WD}}\left(\mathrm{Mg} \cdot \mathrm{ha}^{-1}\right)$ & CCWI & $\overline{\mathrm{DW}_{\mathrm{CC}}\left(\mathrm{Mg} \cdot \mathrm{ha}^{-1}\right)}$ & $\mathrm{DW}_{\mathrm{WD}}\left(\mathrm{Mg} \cdot \mathrm{ha}^{-1}\right)$ & CCWI \\
\hline Cowpea & $3.89 \mathrm{bc}$ & $0.61 \mathrm{~b}$ & $11.8 \mathrm{~b}$ & $2.37 \mathrm{bc}$ & $0.60 \mathrm{c}$ & $16.8 \mathrm{ab}$ \\
\hline Velvet bean & 0.98 & $3.62 \mathrm{a}$ & $0.8 \mathrm{c}$ & $2.78 \mathrm{cb}$ & $2.04 \mathrm{ab}$ & $1.6 \mathrm{~b}$ \\
\hline Lablab & - & - & - & $3.71 \mathrm{~b}$ & $1.36 \mathrm{bc}$ & $3.4 \mathrm{~b}$ \\
\hline Peanut & - & - & - & $1.07 \mathrm{cb}$ & $2.89 \mathrm{a}$ & $0.4 \mathrm{~b}$ \\
\hline
\end{tabular}

${ }^{\mathrm{z}}$ Means within the same column followed by the same letter do not differ statistically based on the Duncan's multiple range test $(P<0.05)$.

$\mathrm{CC}$, cover crop; CCWI, cover crop weed index; $\mathrm{DW}_{\mathrm{CC}}$, cover crop shoot dry weight; $\mathrm{DW}_{\mathrm{WD}}$, weed dry weight.

Table 5. Cover crop $(\mathrm{CC})$ shoot dry weight accumulation $\left(\mathrm{DW}_{\mathrm{CC}}\right)$; weed dry weight accumulation $\left(\mathrm{DW}_{\mathrm{WD}}\right)$, and cover crop weed index (CCWI) for summer cover crops from 2004 to 2005 .

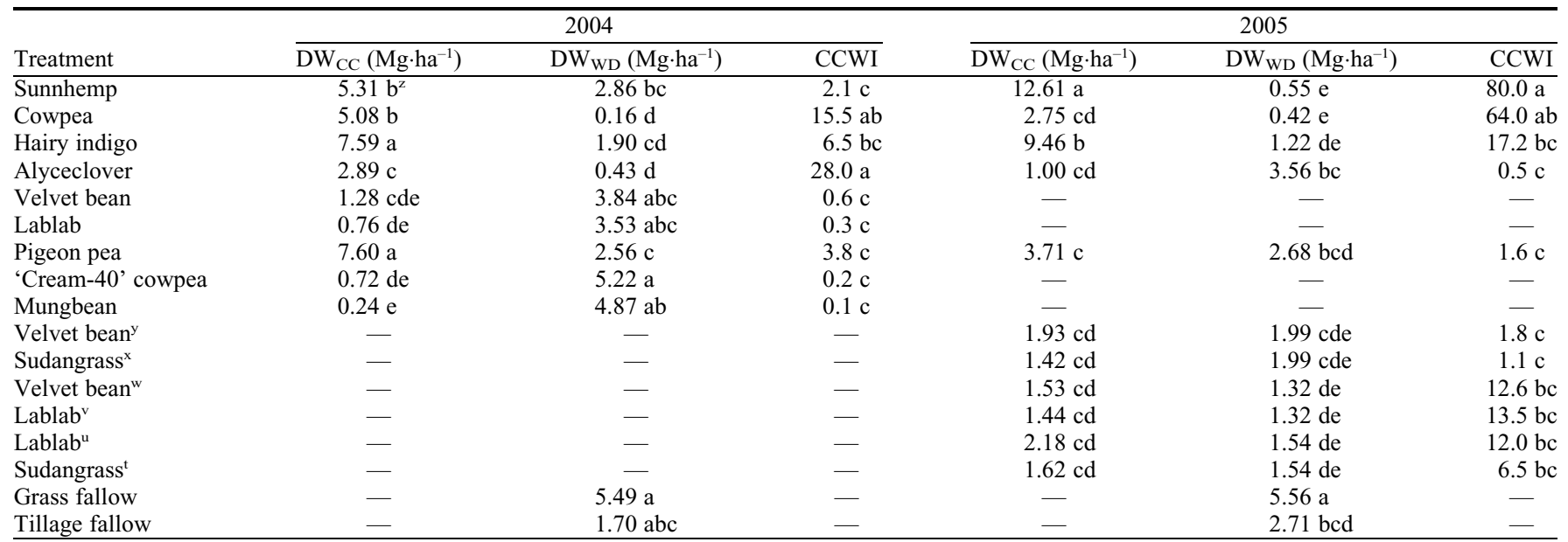

${ }^{2}$ Means within the same column followed by the same letter do not differ statistically based on the Duncan's multiple range test $(P<0.05)$.

${ }^{y}$ Velvet bean mixed with sudangrass $(50 / 50)$.

${ }^{\mathrm{x}}$ Sudangrass mixed with velvet bean $(50 / 50)$.

"Velvet bean mixed with lablab $(50 / 50)$.

${ }^{v}$ Lablab mixed with velvet bean $(50 / 50)$.

"Lablab mixed with sudangrass $(50 / 50)$.

tSudangrass mixed with lablab (50/50).

$\mathrm{CC}$, cover crop; CCWI, cover crop weed index; $\mathrm{DW}_{\mathrm{CC}}$, cover crop shoot dry weight; $\mathrm{DW}_{\mathrm{WD}}$, weed dry weight.

et al. (2004) under tropical conditions, but superior to the results from Balkcom and Reeves (2005).

Hairy indigo performed consistently well, and average DW production was $8.0 \mathrm{Mg} \cdot \mathrm{ha}^{-1}$, similar to values reported by Reddy et al. (1986). Overall pigeon pea DW accumulation was $5.7 \mathrm{Mg} \cdot \mathrm{ha}^{-1}$. Reported values ranged from $4.5 \mathrm{Mg} \cdot \mathrm{ha}^{-1}$ under tropical conditions (Mafongoya and Dzowela, 1999) to 9.5 $\mathrm{Mg} \cdot \mathrm{ha}^{-1}$ in Florida (Reddy et al., 1986). The steep decline in DW accumulation in 2005 (Table 5) was related to hairy indigo selfseeding in plots during 2005. 'Iron Clay' cowpea averaged $3.5 \mathrm{Mg} \cdot \mathrm{ha}^{-1}$, similar to values reported by Muir (2002). Lablab (Lablab purpureus L.) had inconsistent biomass production, and overall DW accumulation was only $2.2 \mathrm{Mg} \cdot \mathrm{ha}^{-1}$. Similar values were reported by Muir (2002), but others reported higher values (Carsky et al., 2001). Alyceclover accumulated to $2.6 \mathrm{Mg} \cdot \mathrm{ha}^{-1}$ whereas velvet bean produced only 1.7 $\mathrm{Mg} \cdot \mathrm{ha}^{-1}$, which was similar to the findings of Creamer and Baldwin (2000) but lower than values reported by Carsky et al. (2001).
This may be the result of the low germination rate and subsequent uneven $\mathrm{CC}$ plant stand (data not shown). Dry matter production of peanut (Arachis hypogea L.) in 2003 and 'Cream 40' cowpea, and mung bean [Vigna radiata (L.) R. Wilczek], in 2004 was low, because of their poor adaptation to the sandy soils and their failure to compete with weeds successfully (Tables 4 and 5).

Weed suppression was associated with CC biomass production; thus, sunnhemp, hairy indigo, and cowpea, followed by alyceclover, provided outstanding to excellent weed control and the highest CCWI values. In general, the single-species velvet bean CC provided only poor to moderate weed control $(\mathrm{CCWI}=0.6-1.6)$, which may have been related to the use of a more erect-type cultivar.

Overall weed reduction across years (2002-2005) was greatest for 'Iron Clay' cowpea $(90 \%$ lower weed biomass compared with control plots, the grass fallow) followed by sunnhemp (77\%), alyceclover (74\%), and hairy indigo (64\%). Tillage fallow was less effective in reducing weeds compared with the better performing $\mathrm{CC}$, with an average reduction of $60 \%$. Sunnhemp and cowpea both provided outstanding weed control whereas use of alyceclover and hairy indigo resulted in excellent weed control. Relatively low weed reduction for alyceclover and hairy indigo during 2003 and 2005 was related to alyceclover self-seeding in hairy indigo plots (2003) and hairy indigo self-seeding in alyceclover plots (2005).

Use of velvet bean, on the other hand, reduced weed growth by only $42 \%$ and had a CCWI of 1.2. These results contrasted with reports by Caamal-Maldonado et al. (2001), who observed a $68 \%$ weed reduction in maize plots using a more prostrate type of velvet bean; and contrasted with the findings of Carsky et al. (2001), who also reported excellent weed suppression in maize. These differences may be related to the poor germination, nodulation, vigor, and competitiveness of the bushy type that was used in our studies.

Combining lablab with velvet bean and sorghum-sudangrass in 2005 , on the other hand, resulted in excellent weed control (CCWI > 12). This may be related to the 
effect of increased $\mathrm{CC}$ diversity facilitating more effective competition with weeds, similar to the findings reported by Kabir and Koide (2002) and Karpenstein-Machan and Stuelpnagel (2000). Intercropping of velvet bean with sorghum-sudangrass, on the other hand, provided only moderate weed control.

The presence of alyceclover, hairy indigo, and cowpea as volunteer crops shows that some of these crops demonstrate their potential for reseeding in subsequent years, as a result of their capacity to produce large numbers of dormant or hard-coated seeds. These species would be able to become part of the soil seed bank and would germinate over many years as, suggested by BenechArnold et al. (2000) and Teasdale et al. (2004), which could provide a cost-effective self-sustaining practice in a mature citrus system.

Winter cover crop study. Radish and winter rye produced the most biomass of all single-species winter CC (Table 6). Radish accumulated an average $3.8 \mathrm{Mg} \cdot \mathrm{ha}^{-1} \mathrm{com}-$ pared with $1.6 \mathrm{Mg} \cdot \mathrm{ha}^{-1}$ reported by Vyn et al. (2000). However, Justes et al. (1999) reported values up to $6.4 \mathrm{Mg} \cdot \mathrm{ha}^{-1}$ with no N added. Winter rye generated $3.4 \mathrm{Mg} \cdot \mathrm{ha}^{-1}$, which was similar to results by Ngouajio and Mennan (2005), but a lower amount compared with the 5 to $10 \mathrm{Mg} \cdot \mathrm{ha}^{-1}$ reported by Bauer and Reeves (1999) and RebergHorton et al. (2005). Crimson clover yielded 2.9 $\mathrm{Mg} \cdot \mathrm{ha}^{-1}$, which was similar to values reported by Schomberg and Endale (2004), but lower than the $4.9 \mathrm{Mg} \cdot \mathrm{ha}^{-1}$ reported by Odhiambo and Bomke (2001).

Use of a triple CC mix (winter rye + crimson clover + radish) resulted in the greatest biomass $\left(8.0 \mathrm{Mg} \cdot \mathrm{ha}^{-1}\right)$, which was about two times greater than the $3.8 \mathrm{Mg} \cdot \mathrm{ha}^{-1}$ for single-species radish. KarpensteinMachan and Stuelpnagel (2000) reported similar findings for a mixed $\mathrm{CC}$ system in Germany consisting of winter rye and crimson clover, and for winter rye with winterpea (Pisum sativum L. ssp. arvense (L.) Poir). Similar results were reported by Juskiw et al. (2000) for small-grain cereals underseeded with legumes in Canada.

During the 2004-2005 winter season, DW accumulation of the triple CC mix was comparable to the 8 to $9 \mathrm{Mg} \cdot \mathrm{ha}^{-1}$ produced by summer $\mathrm{CC}$ systems in 2004, but lower than the 10 to $14 \mathrm{Mg} \cdot \mathrm{ha}^{-1}$ obtained in 2005 . This result may be related to the added biodiversity and complementary traits of the $\mathrm{CC}$ mixture constituents, with the vigorous and rapid growth of the winter rye crop providing allelopathic activity, the deep radish roots breaching any soil compaction zones, and the crimson clover supplying $\mathrm{N}$ through $\mathrm{N}$ fixation. This interaction between root and canopy structure may facilitate improved adaptation to different ecological niches, soil types, and weather conditions, providing multiple benefits and improved nutrient retention, cycling, and $\mathrm{N}$ fixation as suggested by Gliessman (1998), Altieri (1999), and Karpenstein-Machan and Stuelpnagel (2000). Mixed CC systems thus mimic natu-

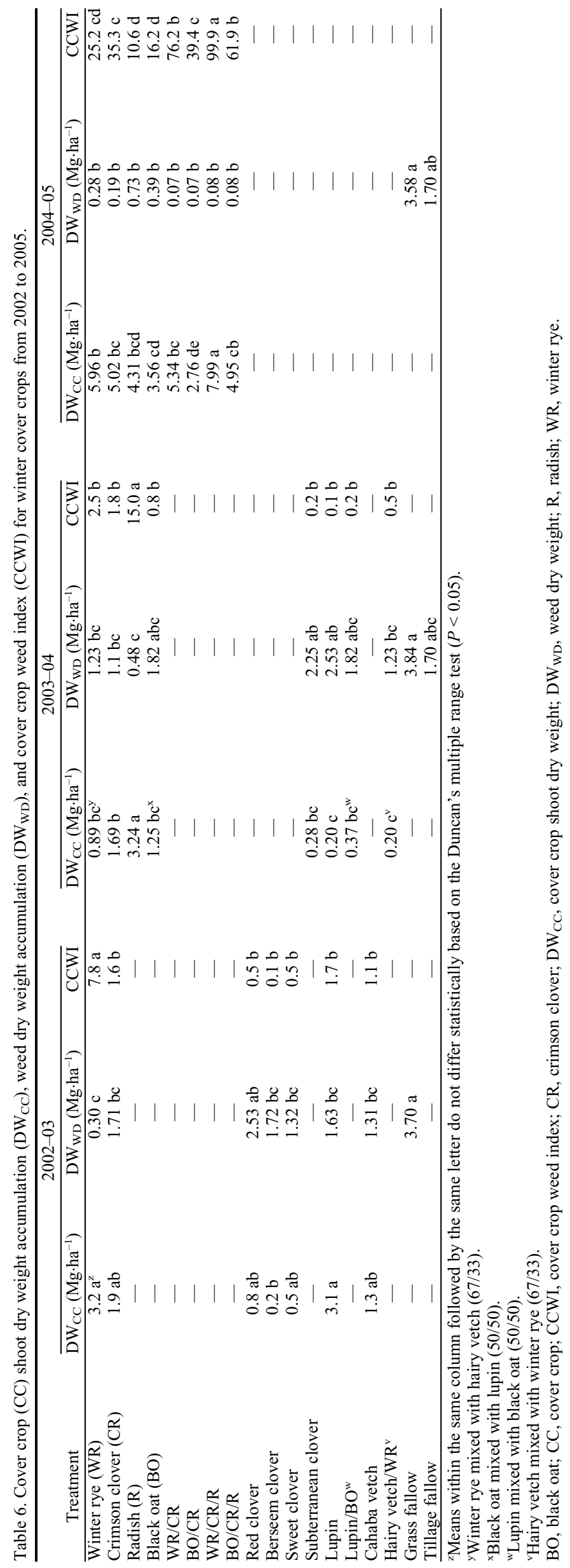



fore compete more effectively with weeds, which would explain the superior performance of these mixed systems.

Dry weight accumulation by red clover (Trifolium pratense L.), berseem clover (Trifolium alexandrinum L.), sweet clover (Melilotus officinalis L.), subterranean clover, cahaba white vetch (Vicia sativa L.), and lupin (Lupinus angustifolius L.) was relatively low (Table 6). This result may be related to these crops' greater need for moisture during the uneven rainfall distribution in 2002 to 2004 (data not shown); to low soil organic matter, $\mathrm{pH}$, and $\mathrm{K}$ values; to poor initial nodulation and growth by these crops, hampering their ability to compete effectively with weeds; and to an overall poor adaptation of these crops to coarse sandy soils compared with cowpea, hairy indigo, alyceclover, and sunnhemp. Chicken manure was applied only to tree rows to reduce weed vigor and to determine growth of leguminous $\mathrm{CC}$ under a no-external $\mathrm{N}$ regimen.

During Winter 2004-2005, intercropping two- and three-species mixtures reduced weed growth by $98 \%$ compared with the for crimson clover, winter rye, and radish monocrops were $78 \%$ to $84 \%$. For winter rye, weed suppression may be related to allelopathy (Reberg-Horton et al., 2005; Weston, 1996). Compared with the best CC, tillage fallow was less effective in reducing weeds, with reductions in weed biomass averaging only $55 \%$.

During the winter of 2002-2003, winter rye had the greatest CCWI (excellent weed control) followed by crimson clover and lupin, which provided moderate weed control. Use of other legumes did not greatly affect weed growth and thus provided poor weed control possibly as a result of low plant populations associated with low germination, ineffective nodulation, and poor adaptation to Florida soils and environmental conditions.

During the 2003-2004 winter growing season, despite unfavorable growing conditions resulting from lack of tillage, radish reduced weed growth by $90 \%$ to $95 \%$. Overall CCWI values were greatest for radish, which provided outstanding weed control, whereas values for winter rye and crimson clover were intermediate, indicative of moderate weed control. Use of other leguminous $\mathrm{CC}$ did not greatly reduce weed growth and resulted in poor weed control. During the winter of 2004-2005, the CCWI values varied from excellent for radish to outstanding for the other monocrops and intercropmixtures resulted in the highest CCWI values. The outstanding weed control of mixed systems may be related to greater competition provided by the $\mathrm{CC}$ and allelopathic activities of radish, possibly as a result of the glucosinolate content reported for radish and other members of the Brassicaceae family (Morra and Kirkegaard, 2002; Norsworthy et al., 2005). Allelopathy has been reported also for black oat (Bauer and Reeves, 1999). ral systems, and crop components may theregrass fallow (Table 6). Corresponding values ping systems. Two- and three-species
Observed weeds species did not follow any special pattern associated with ACC treatments. The main species observed in field during late spring, summer, and early fall (warm-season weeds) were bermudagrass [Cynodon dactylon (L.) Pers.], large crabgrass [Digitaria sanguinalis (L.)], bahiagrass (Paspalum notatum Fluegge), and goosegrass [Eleusine indica (L.) Gaertn]. In winter and early spring, the dominant weeds found were red sorrel (Rumex acetosella L.), oldfield toadflax [Linaria canadensis (L.) Dumont], and common venuslookingglass [Triodanis perfoliata (L.) Nieuwl.].

There appears to be excellent prospective for the use of sunnhemp, 'Iron Clay' cowpea, alyceclover, and hairy indigo as summer CC for weed suppression in organic citrus production systems. Alyceclover and 'Iron Clay' cowpea had more compact low-growing canopies, which would facilitate their integration into newly planted citrus production systems. Based on our experiments, we propose investigating the potential for a new system using the low-growing alyceclover in a 1.6- to $1.8-\mathrm{m}$ strip in tree rows, and 'Iron Clay' cowpea in an area adjacent to the alyceclover. If it would be desirable to apply mulch to the tree row during the winter season, a strip of sunnhemp could be planted in the row middle and later mulched for this purpose.

Alternatively, use of 'Iron Clay' cowpea in row middles may be preferable as discussed earlier. During the winter season, we propose the use of a system consisting of a tree strip planted with a mixture of crimson clover and black oat as winter CC because of their compact canopy and low probability of competition with citrus trees for light. Intercropping winter rye with crimson clover and radish would be desirable for row middles.

\section{Perennial cover crop study}

Annual CC outperformed PP treatments and produced much greater DW accumulation $\left(\mathrm{DW}_{\mathrm{CC}}\right)$ and were also more effective in suppressing weeds across all the seasons and years, except in 2004 when 'Cream-40' cowpea was used as CC (Table 7). Overall $\mathrm{DW}_{\mathrm{CC}}$ values were greater for summer $\mathrm{CC}$ (sunnhemp and cowpea) than for crimson clover, except in 2004. The overall $\mathrm{DW}_{\mathrm{CC}}$ were as follows: sunnhemp $>$ crimson clover $>$ 'Cream-40' cowpea. The three-species winter CC mix (winter rye, crimson clover, and radish) generated $7.4 \mathrm{Mg} \cdot \mathrm{ha}^{-1}$ and outperformed single-species treatments. Overall weed $\mathrm{DW}_{\mathrm{wd}}$ values were consistently lower in ACC when compared with $\mathrm{PP}_{\text {su, }}$, which was the best performing PP system.

The ranking of weed DW $\left(\mathrm{DW}_{\mathrm{wd}}\right)$ was as follows: 'Cream-40' cowpea $>$ crimson clover $>$ sunnhemp $>$ winter $C C$ triple mix. The CCWI score varied from outstanding weed control $($ CCWI $>20)$ for triple mix and sunnhemp, to moderate weed control (CCWI = 1-3) for crimson clover, and poor weed control for 'Cream-40' cowpea and PP. In comparison with ACC systems, weed DW was $1067 \%$ greater in the $\mathrm{PP}_{\mathrm{su}}$ system.

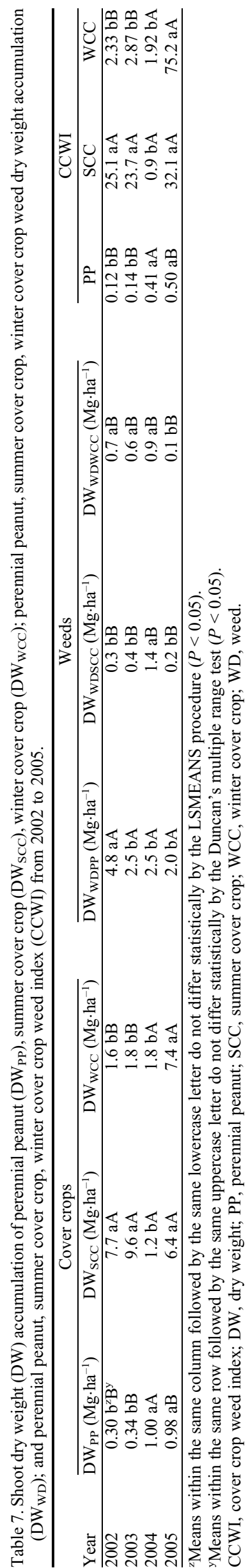


Low initial DW production in the PP plots may have been related to slow initial growth in 'Florigraze' (Prine et al., 1986). In addition, lack of supplemental irrigation combined with low organic matter content and poor water retention capacity of the sandy soil may have further hampered initial growth and leaf area expansion.

Complete row closure by PP only occurred during the third year of growth, probably as a result of pronounced weed competition during the first 2 years. These findings agree with those reported by Williams (1993), but they are different from results of Ruiz et al. (2000), who reported row closure within 1 year. However, in that case, mechanical or chemical weed control along with supplemental fertilizers and irrigation were applied. Synthetic fertilizers and herbicides are not permitted in organic production, but irrigation could be evaluated in future studies for enhancing PP establishment and growth.

Relatively poor performance of $\mathrm{PP}$ in our studies could be explained by the competition between PP and grassy weeds, and is consistent with an earlier report (Dunavin, 1992). Canudas et al. (1989) concluded that grass weeds hampered PP establishment and reduced PP yield by $50 \%$ as a result of competition. Dunavin (1992), and Valencia et al. (1999) reported similar or lower yields for PP mixed with grasses. With competition from grasses, PP rhizome storage reserves may become depleted, resulting in reduced regrowth and poor performance in following years (Saldivar et al., 1992). Low inherent soil K levels may also have hampered PPRhizobium activity as suggested by Slattery et al. (2001).

Based on field observations, frequent mowing during the first year greatly reduced the incidence of broadleaf weeds and favored the prevalence of $\mathrm{C}-4$ grass species, including bahiagrass (Paspalum notatum Fluegge) and bermudagrass (Cynodon dactylon L. Pers.), similar to previously reported results (Paterson et al., 1996; Wright et al., 2003). These C-4 grasses can grow more vigorously and outcompete PP because of their higher growth rates compared with $\mathrm{PP}$, which is a $\mathrm{C}-3$ plant (Newman et al., 2005).

The effectiveness of ACC in suppressing weeds compared with PP may be related to higher growth rates of ACC, the use of mechanical tillage disrupting weed growth cycles, and allelopathic action of winter rye (Reberg-Horton et al., 2005). The superiority of weed suppression for ACC, especially by the triple mix (winter rye + crimson clover + radish) and sunnhemp was probably related to superior resource preemption by these ACC systems (Craine et al., 2005).

Although $\mathrm{PP}_{\mathrm{su}}$ had low CCWI values and did not effectively suppress weeds during the first years, PP has been shown to be able to persist under adverse conditions (French and Prine, 1991). As was expected, over time PP gradually became more competitive, although its overall performance was still inferior to ACC. However, in addition to weed suppression, other potential advantages of PP include additional income from PP hay and forage (French et al., 2001).

Because it is very important to ensure a clean and weed-free seed bed for PP planting (Williams, 1993), use of repeated tillage followed by $\mathrm{CC}$ such as sunnhemp and winter rye may be beneficial to reduce weed populations in organic systems for a minimum of 1 year before planting PP. In terms of PP systems, we also propose the use of an integrated management system with PP being planted in early summer in row middles following repeated rototilling of a preceding winter rye CC. Annual compact, self-seeding $\mathrm{CC}$ can be planted near young trees, complemented with manure or natural fertilizer amendments applied to the tree rows only. When the trees are 5 to 6 years old and the PP is established, sheep can be introduced to the system to graze the row middles. This may reduce labor and energy requirements for maintaining a short canopy. Additional research is needed to assess the fate of $\mathrm{N}$ (immobilization and release) in the different $\mathrm{N}$ soil pools derived from either $\mathrm{CC}$ or added manures or fertilizers in these sandy soils.

Although the effect of $\mathrm{CC}$ on citrus tree performance and yield was not the primary objective of this work, it should be noted that for both ACC and PCC, tree height and diameter were unaffected by treatments (data not shown). Similarly, there was no $\mathrm{CC}$ treatment effect on citrus leaf $\mathrm{N}$ concentration. During 2005, fruits were harvested for the first time and yield, degree Brix, juice acidity, and the Brix-to-acid ratio were also unaffected by treatments (data not shown).

\section{CONCLUSIONS}

Annual cover crops can provide growers with an effective method for managing weeds in organic citrus systems. Although the use of PP may provide growers with some additional income after initial establishment, the slow initial growth may hamper successful establishment in fields that have excessively high levels of persistent weeds.

Overall dry matter and weed suppression in a newly established organic citrus orchard varied by $\mathrm{CC}$ species and by season. In general, summer $\mathrm{CC}$ produced the greatest biomass, with sunnhemp $>$ hairy indigo $>$ cowpea $>$ alyceclover. Although pigeon pea had consistent biomass yields, its weed suppression capacity was not always consistent. The most consistent and best performing winter CC were radish, winter rye, and crimson clover.

Throughout the course of the study, use of selected CC provided excellent weed control, which was superior to other methods including tillage, thus showing the potential of CC for successful weed suppression in organic citrus groves. Use of two- or three-species winter CC mixes resulted in higher DW accumulation and more effective weed suppression, likely as a result of the interaction among system components.
In general, establishment of PP in the organic citrus orchard was slow, with very poor to poor initial weed suppression, resulting from slow initial growth and poor competition with high weed populations. Compared with $\mathrm{PP}, \mathrm{ACC}$ provided a greater level of weed control. For both PP and ACC, weed biomass was typically inversely related to DW content of either PP or ACC, probably as a result of competition for light, water, and nutrients. The CCWI proved to be an effective tool for quantifying $\mathrm{CC}$ performance in terms of weed suppression, and can be used by organic fruit producers for determining the optimal CC mix for their orchard system.

\section{Literature Cited}

Altieri, M. 1999. The ecological role of biodiversity in agroecosystems. Agr. Ecosyst. Environ. 74:19-31.

Athearn, K. 2004. Efficacy of environmental labeling: An economic analysis with two examples from Florida agriculture. University of Florida, Gainesville, FL. PhD Diss.

Bailey, K.L. and G. Lazarovits. 2003. Suppressing soil-borne diseases with residue management and organic amendments. Soil Tillage Res. 72:169-180.

Balkcom, K. and D.W. Reeves. 2005. Sunn-hemp utilized as a legume cover crop for corn production. Agron. J. 97:26-31.

Baltensperger, D.D., G.M. Prine, and R.A. Dunn. 1986. Root-knot nematode resistance in Arachis glabrata. Peanut Sci. 13:78-80.

Barberi, P. and M. Mazzoncini. 2001. Changes in weed community composition as influenced by cover crops and management systems in continuous corn. Weed Sci. 49:491-499.

Bauer, P.J. and W. Reeves. 1999. A comparison of winter cereal species and planting dates as residue cover for cotton grown with conservation tillage. Crop Sci. 39:1824-1830.

Benech-Arnold, R.L., R.A. Sanchez, F. Forcella, B.C. Kruk, and C.M. Ghersa. 2000. Environmental control of dormancy in weed seed banks in soil. Field Crop Res. 67:105-122.

Bond, W. and A.C. Grundy. 2001. Non-chemical weed management in organic farming systems. Weed Res. 41:383-405.

Caamal-Maldonado, J., J. Jiménez, A. Torres, and A. Anaya. 2001. The use of allelopathic legume cover and mulches species for weed control in cropping systems. Agron. J. 93:27-36.

Canudas, E.G., K.H. Quesenberry, L.E. Sollenberger, and G.M. Prine. 1989. Establishment of two cultivars of rhizoma peanut as affected by weed control and planting rate. Trop. Grass. $23: 162-170$.

Carsky, R.J., B. Oyewole, and G. Tian. 2001. Effect of phosphorus application in legume cover crop rotation on subsequent maize in the savanna zone of West Africa. Nutr. Cycling Agroecosyst. 59:151-159.

Craine, J.M., J. Fargione, and S. Sugita. 2005. Supply pre-emption, not concentration reduction, is the mechanism of competition for nutrients. New Phytol. 166:933-940.

Creamer, N.G. and K.R. Baldwin. 2000. An evaluation of summer cover crops for use in vegetable production systems in North Carolina. HortScience 35:600-603.

Dunavin, L.S. 1992. Florigraze rhizoma peanut in association with warm-season perennial grasses. Agron. J. 84:148-151.

Fennimore, S. and L. Jackson. 2003. Organic amendment and tillage effects on vegetable 
field weed emergence and seed banks. Weed Technol. 17:42-50.

Florida Agricultural Statistics Service. 2006. Citrus summary 2004-2005. Florida Dept. Agr. and Consumer Serv. Tallahassee, FL. 1 June 2006. $<$ http://www.nass.usda.gov/Statistics_by_State/ Florida/Publications/Citrus/cs/2004-05/cs0405 all.pdf $>$.

French, E.C. and G.M. Prine. 1991. Perennial peanut establishment guide. SS-AGR-35. Florida Cooperative Extension Service, IFAS, University of Florida, Gainesville, FL.

French, E.C., G.M. Prine, and A.R. Blount. 2001. Perennial peanut: An alternative forage of growing importance. SS-AGR-39. Florida Cooperative Extension Service, IFAS, University of Florida, Gainesville, FL.

Gallagher, R.S., E.C.M. Fernandez, and E.L. McCallie. 1999. Weed management through short-term improved fallows in tropical agroecosystems. Agroforest. Syst. 47:197-221.

Gliessman, S. 1998. Agroecology: Ecological processes in sustainable agriculture. Sleeping Bear Press, Chelsea, MI.

Jordan, N., J. Zhang, and S. Huerd. 2000. Arbuscular-mycorrhizal fungi: Potential roles in weed management. Weed Res. 40:397-410.

Juskiw, P.E., J.H. Helm, and D.F. Salmon. 2000. Forage yield and quality for monocrops and mixtures of small grain cereals. Crop Sci. 40:138-147.

Justes, E., M. Bruno, and B. Nicolardot. 1999. Comparing the effectiveness of radish cover crop, oilseed rape volunteers and oilseed rape residues incorporation for reducing nitrate leaching. Nutr. Cycling Agroecosyst. 55:207-220.

Kabir, Z. and R.T. Koide. 2002. Effect of autumn and winter mycorrhizal cover crops on soil properties, nutrient uptake and yield of sweet corn in Pennsylvania, USA. Plant Soil 238:205-215.

Karpenstein-Machan, M. and R. Stuelpnagel. 2000. Biomass yield and nitrogen fixation of legumes monocropped and intercropped with rye and rotation effects on a subsequent maize crop. Plant Soil 218:215-232.

Kremer, R. and J. Li. 2003. Developing weedsuppressive soils through improved soil quality management. Soil Tillage Res. 72:193-202.

Liebman, M. and A. Davis. 2000. Integration of soil, crop and weed management in low-externalinput farming systems. Weed Res. 40:27-47.

Mader, P., A. Fliebach, D. Dubois, L. Gunst, P. Fried, and U. Niggli. 2002. Soil fertility and biodiversity in organic farming. Science 296:1694-1697.

Mafongoya, P.L. and B.H. Dzowela. 1999. Biomass production of the tree fallows and their residual effect on maize in Zimbabwe. Agrofor. Syst. 47:139-151.

Morra, M.J. and J.A. Kirkegaard. 2002. Isothiocyanate release from soil-incorporated brassica tissues. Soil Biol. Biochem. 34:1683-1690.

Muir, J. 2002. Hand-plucked forage yield and quality and seed production from annual and short-lived perennial warm-season legumes fertilized with composted manure. Crop Sci. 42:897-904

Mullahey, J.J., R.E. Rouse, and E.C. French. 1994. Perennial peanut in citrus groves: An environmentally sustainable agricultural system, p. 479-483. In: J. Campbell (ed.). Proceedings
Second Conference Environmentally Sound Agriculture. ASAE, St. Joseph, MI.

Muraro, R.P., F.M. Roka, and R.E. Rouse. 2003. Budgeting costs and returns for southwest Florida citrus production, 2002-2003. EDIS FE 434, Florida Cooperative Extension Service, IFAS, University of Florida, Gainesville, FL.

Newman, Y.C., L.E. Sollenberger, and K.J. Boote. 2005. Temperature and carbon dioxide effects on nutritive value of rhizoma peanut herbage. Crop Sci. 45:316-321.

Ngouajio, M. and M.E. McGiffen. 2002. Going organic changes weed population dynamics. HortTechnology 12:590-596.

Ngouajio, M. and H. Mennan. 2005. Weed populations and pickling cucumber (Cucumis sativus) yield under summer and winter cover crop systems. Crop Prot. 24:521-526.

Norsworthy, J.K., L. Brandenberger, N. Burgos, and M. Riley. 2005. Weed suppression in Vigna unguiculata with a spring-seeded Brassicaceae green manure. Crop Prot. 24:441-447.

Odhiambo, J. and A. Bomke. 2001. Grass and legume cover crop effects on dry matter and nitrogen accumulation. Agron. J. 93:299-307.

Paterson, E., E.A. Rattray, and K. Killham. 1996. Effect of elevated $\mathrm{CO}_{2}$ concentration on Cpartitioning and rhizosphere $\mathrm{C}$-flow for three plant species. Soil Biol. Biochem. 28:195-201.

Perez-Nieto, J., E. Valdes-Velarde, M.E. HernandezSan Roman, and V. Ordaz-Chaparro. 2005. Rain, runoff, and soil erosion in shaded coffee agroforestry systems. Agrociencia 39:409-418.

Perin, A., R.H. Silva, S. Urquiaga, J.G. Marinho, and P.R. Cecon. 2004. Producao of fitomass, acumulo de nutrients e fixacao biologica de nitrogenio por adubos verdes em cultivo isolado e consorciado. Pesq. Agrop. 39:35-40.

Prine, G.M., L.S. Dunavin, J.E. Moore, and R.D. Roush. 1981. 'Florigraze' rhizoma peanut: A perennial forage legume. Fla. Agric. Exp. Stn. Circ. S-275. IFAS, University of Florida, Gainesville, FL.

Prine, G.M., L.S. Dunavin, J.E. Moore, and R.D. Roush. 1986. Registration of 'Florigraze' rhizoma peanut. Crop Sci. 26:1084-1085.

Ramos, M.G., M.A. Villatoro, S. Urquiaga, B.J. Alves, and R.M. Boddey. 2001. Quantification of the contribution of biological nitrogen fixation to tropical green manure crops and the residual benefit to a subsequent maize crop using ${ }^{15} \mathrm{~N}$-isotope techniques. J. Biotechnol. 91:105-115.

Reberg-Horton, S.C., J.D. Burton, D.A. Danehower, G. Ma, D.W. Monks, J.P. Murphy, N.N. Ranells, J.D. Williamson, and N.G. Creamer. 2005. Changes over time in the allelochemical content of ten cultivars of rye (Secale cereale L.). J. Chem. Ecol. 31:179-193.

Reddy, K., A.R. Soffes, and G.M. Prine. 1986. Tropical legumes for green manure. I. Nitrogen production and the effects on succeeding crop yields. Agron. J. 78:1-4.

Reganold, J.P., J.D. Glover, P.K. Andrews, and H.R. Hinman. 2001. Sustainability of three apple production systems. Nature 410:926929.

Roder, W., S. Maniphone, and B. Keoboulapha. 1998. Pigeon pea for fallow improvement in slash-burn systems in the hills of Laos? Agroforest. Syst. 39:45-57.
Roe, N.E., P.J. Stofella, and H.H. Bryan. 1994. Growth and yield of bell pepper and winter squash grown with organic and living mulches. J. Amer. Soc. Hort. Sci. 119:1193-1199.

Rouse, R.E. and J.J. Mullahey. 1997. Perennial peanut groundcover in citrus orchard row middles and discussion of potential environmental benefits. Proc. Fla. St. Hort. Soc. 110:79-82.

Ruiz, T.M., R. Ramos-Santana, and A. SotomayorRios. 2000. Establishment of rhizoma perennial peanut (Arachis glabrata) under irrigation at two semiarid sites in the Caribbean. J. Agr. Univ. P. R. 84:105-114.

Saldivar, A.J., W.R. Ocumpaugh, R.R. Gildersleeve, and G.M. Prine. 1992. Total non-structural carbohydrates and nitrogen of 'Florigraze' rhizoma peanut. Agron. J. 84:439-444.

SAS Institute, Inc. 2002. The SAS system for windows 9.0. SAS Institute, Inc., Cary, NC.

Schomberg, H. and D.M. Endale. 2004. Cover crop effects on nitrogen mineralization and availability in conservation tillage cotton. Biol. Fertil. Soils 40:398-405.

Slattery, J.F., D.R. Coventry, and W.J. Slattery. 2001. Rhizobial ecology as affected by the soil environment. Aust. J. Exp. Agr. 41:289-298.

Sooby, J. 2003. State of the states. Organic farming systems research at land grant institutions 2001-2003. 2nd ed. Organic Farming Research Foundation, Santa Cruz, CA.

Teasdale, J.R., R.W. Mangum, J. Radhakrishnan, and M.A. Cavigelli. 2004. Weed seed bank dynamics in three organic farming crop rotations. Agron. J. 96:1429-1435.

Tucker, D.P., A.K. Alva, L.K. Jackson, and T.A. Wheaton (eds.). 1995. Nutrition of Florida citrus trees. SP-169. Univ. of Florida, Gainesville, FL.

Valencia, E., M.J. Williams, C.C. Chase, L.E. Sollenberger, A.C. Hammond, R.S. Kalmbacher, and W.E. Kunkle. 1999. Management effects on herbage yield and botanical composition of rhizoma peanut-mixed grass associations. Agron. J. 91:431-438.

Vyn, T.J., G. Faber, K.J. Janovicek, and E.G. Beauchamp. 2000. Cover crop effects on nitrogen availability to corn following wheat. Agron. J. 92:915-924.

Wagger, M.G., M.L. Cabrera, and N.N. Ranells. 1998. Nitrogen and carbon cycling in relation to cover crop residue quality. J. Soil Water Conserv. 214:210-218.

Walz, E. 1999. Final results of the third biennial organic farmers' survey. Organic Farming Research Foundation, Santa Cruz, CA.

Wang, K.H., R. McSorley, A. Marshall, and R.N. Gallaher. 2006. Influence of organic Crotalaria juncea hay and ammonium nitrate fertilizers on soil nematode communities. Appl. Soil Ecol. $31: 186-198$.

Weston, L. 1996. Utilization of allelopathy for weed management in agroecosystems. Agron. J. 88:860-866.

Williams, M.J. 1993. Planting date and preplant tillage effects on emergence and survival of rhizoma perennial peanut. Crop Sci. 33:132136.

Wright, G.C., W.B. McCloskey, and K.C. Taylor. 2003. Managing orchard floor vegetation in flood-irrigated citrus groves. HortTechnology 13:668-677. 